\title{
Nitrogen transformations and factors leading to nitrite accumulation in a hypertrophic marine fish culture system
}

\author{
Orit Dvir' ${ }^{1}$ Jaap van Rijn ${ }^{2}$, Amir Neori ${ }^{1, *}$ \\ ${ }^{1}$ Israel Oceanographic and Limnological Research, National Center for Mariculture, Eilat 88112, Israel \\ ${ }^{2}$ Department of Animal Science, Faculty of Agricultural, Food and Environmental Quality Sciences, \\ The Hebrew University of Jerusalem, Rehovot 76100, Israel
}

\begin{abstract}
Nitrogen transformations in a highly eutrophic model ecosystem were studied. The heterotrophic (fish and sedimentation) and autotrophic (seaweed) components of the ecosystem were separated into 3 units. The seaweed purified fish effluents from organic matter and ammonia, and enriched them with dissolved oxygen (DO). Particles were sedimented out and the treated water was recirculated to the fish unit. Both assimilation of ammonia and production of oxidized nitrogen (ToxN) occurred mainly in the seaweed unit. ToxN production potential was highest in organic films on the

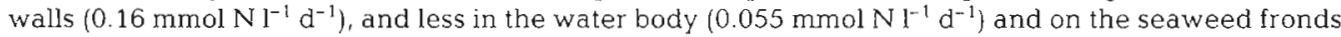

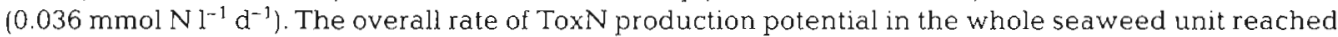
$0.73 \mathrm{~mol} \mathrm{~d}^{-1}$ The specific rate there was $0.74 \mathrm{~g} \mathrm{~N} \mathrm{~m}^{-2} \mathrm{~d}^{-1}$ (expressed per $\mathrm{m}^{2}$ of tank wall), about 3 times the highest published rate for marine nitrification. In the other compartments, processes of production and consumption prevented net Tox $N$ accumulation. Nitrite in the seaweed tanks accumulated in a diumal fashion, at a rate that averaged $50 \%$ of accumulation rate of ToxN. Laboratory incubations of film samples collected from the seaweed unit revealed that, within the ranges of conditions examined (16 to $28^{\circ} \mathrm{C}$ and $\mathrm{pH} 7$ to 9), ToxN accumulated fastest at $\mathrm{pH} 8$ and at higher temperatures. Nitrite accumulation was enhanced as temperatures and $\mathrm{pH}$ values were elevated. Both nitrification and denitrification might have contributed to the observed nitrite accumulation. It was estimated that denitrification in the sedimentation unit consumed up to $19 \%$ of the total daily nitrogen input to the system.
\end{abstract}

KEY WORDS: Hypertrophic marine ecosystems Nitrogen - Nitrite - Nitrification - Denitrification Mariculture $\cdot$ Seaweed Fish $\cdot$ Model

\section{INTRODUCTION}

With the increase in eutrophication of coastal waters and enclosed seawater bodies, the factors that control nitrogen transformations in marine hypertrophic ecosystems become more relevant. The roles in these processes of waterborne bacteria and algae, of sediments and animals and of season are of particular interest. Often, but not always, processes in the sediment dominate nitrate production and consumption in coastal waters, and often the rate of nitrate reduction depends on the rate of ammonification

\footnotetext{
- Addressee for correspondence

E-mail: neori@ocean.org.il
}

and nitrate production (e.g. Blackburn et al. 1988 , Rysgaard et al. 1996).

In open and coastal marine waters, $\mathrm{N}_{2}$ gas and nitrate are the most abundant inorganic nitrogen forms. This situation is in contrast to hypertrophic marine ecosystems where, in addition to these forms, ammonia and nitrite are often present at appreciable concentrations (reviewed by Paasche 1988). Nitrite is extremely toxic to aquatic life and, as such, its accumulation needs to be understood.

As an intermediate product of both nitrification and denitrification, nitrite accumulates when factors prohibit complete oxidation of ammonia to nitrate (nitrification) or complete reduction of nitrate to nitrogenous gases (denitrification). 
Information on nitrite production by marine denitrifiers is scarce, especially for natural hypertrophic seawater (reviewed by Paasche 1988). It may be assumed, however, that the biogeochemical factors controlling marine denitrifiers are similar to those found for freshwater denitrifying isolates. In the latter organisms, nitrite accumulation is influenced by carbon limitation and composition (Almeida et al. 1995, van Rijn et al. 1996), kinetic differences in reductases involved in reduction of nitrate to nitrogen gas (Betlach \& Tiedje 1981), availability of dissolved oxygen (DO) (Hochstein et al. 1984) and light (Barak et al. 1998). Relatively high nitrite concentrations (up to $23 \mu \mathrm{M}$ ) in nutrient-rich coastal seawater have been associated with unstable denitrification rates (Codispoti et al. 1986). Nitrite peaks in lower oceanic layers, known as secondary nitrite maxima, were thought to result from incomplete denitrification at low DO concentrations (Tiedje 1988).

Nitrite accumulation by ammonia oxidizers occurs near the base of the euphotic zone, particularly in nutrient-rich estuarine water (reviewed by Paasche 1988), where it has been associated with a seasonally unstable water column. Rates of oxidation of ammonia and nitrite are believed to be regulated by DO concentration and light intensity (Olson 1981, Helder \& de Vries 1983), and by innate kinetic differences between rates of ammonia and nitrite oxidation (Forster 1974, Poxton et al. 1981, Kaplan 1983, Nijhof \& Bovendeur 1990). The last publication has also documented the extremely slow growth rate of marine nitrifiers, even compared with such bacteria in freshwater

The physical proximity of the organisms responsible for nitrogen transformations and the instability of physicochemical conditions in natural hypertrophic ecosystems hinder their investigation. In this study, results are presented on nitrogen transformations and on factors leading to persistent nitrite accumulation simultaneously with nitrate, in a simplified marine hypertrophic ecosystem. The processes were investigated in a well-defined, compartmentalized model of an intensive mariculture system for fish and seaweed. The system was characterized by steady input rates of water and nutrients and by the daily discharge of the anaerobic sediments (Neori et al. 1993, 1996). Relatively high and persistent production rates of nitrite and nitrate had been found in this system (Krom et al. 1995, Neori et al. 1996). The physical separation between the autotrophic and heterotrophic compartments and the lack of significant sediment buildup have allowed the detailed characterization of these transformations.

\section{MATERIALS AND METHODS}

Experimental system. The culture system has been described in detail elsewhere (Neori et al. 1996). Briefly, the system has 3 main compartments (Fig. 1): a fish tank (1800 l), shaded to prevent phytoplankton growth; 3 identical parallel seaweed recirculating biofilters (each $2130 \mathrm{l}, 3 \mathrm{~m}^{2}$ ) through which the fish tank water is recirculated at an overall rate of about $900 \mathrm{l} \mathrm{h}^{-1}$; and a sedimentation tank (400 l), situated between the fish and the seaweed tanks. The system receives daily $2000 \mathrm{l}$ of clean seawater.

The fish tank was stocked with gilthead seabream Sparus aurata L. at a density of $17 \mathrm{~kg} \mathrm{~m}^{-3}$. The fish were fed daily $(08: 30 \mathrm{~h})$ with $600 \mathrm{~g}$ of a $40 \%$ protein pelleted diet as described by Krom \& Neori (1989). The tanks were aerated and agitated via holes in the tank base. The biofilter tanks were stocked with the green seaweed Ulva lactuca at an initial stocking density of $1 \mathrm{~kg} \mathrm{~m}^{-2}$ (the optimum, based on Neori et al. 1991). The seaweed was harvested weekly and immediately restocked at the original density.

Measurements of inorganic nitrogen transiormations in the culture system. Nitrification rate was defined for practical considerations as the net accumulation rate of total oxidized nitrogen (ToxN $=\mathrm{NO}_{2}{ }^{-}+$ $\mathrm{NO}_{3}{ }^{-}$). Rates of ToxN production in the tanks were calculated from inflow and outflow concentrations of the nitrogenous species, multiplied by the water exchange rates, as in Krom et al. (1995). Potential rates of ToxN production in the tanks were measured by stopping the water exchange, topping up the water with ammonium salt to concentrations between 100 and $150 \mu \mathrm{M}$,

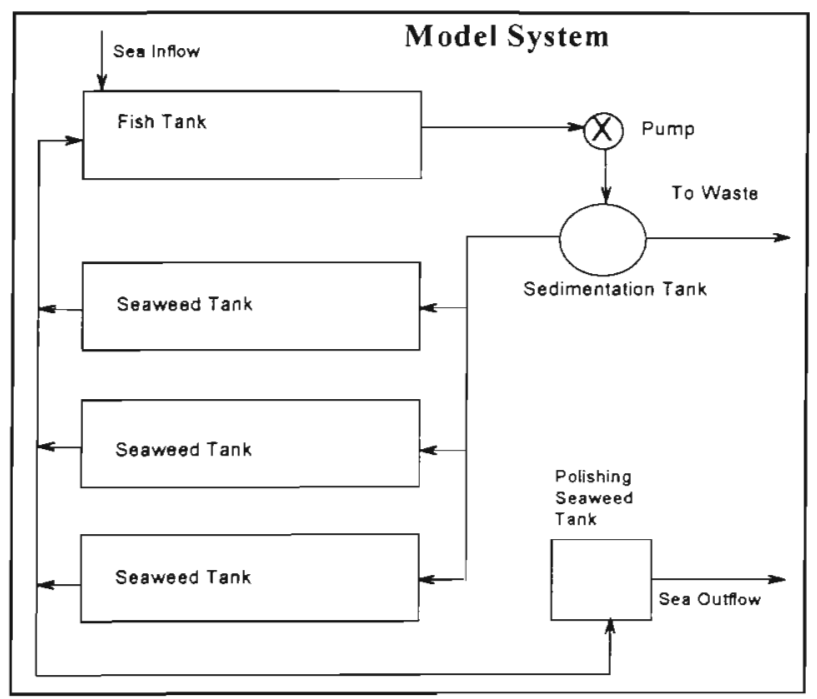

Fig. 1. A schematic diagram of the fishpond-seaweed biofilter system. Arrows indicate the direction of water flow 
sampling the water every 1 to $4 \mathrm{~h}$ and drawing timecourses of ToxN accumulation. Linear regressions provided the desired rates. Replicates with non-significant regression lines were discarded.

ToxN production rates were measured in the 3 main compartments comprising the model mariculture system: the seaweed tanks, the fish tank and the sedimentation tank. Prior to the measurements the seaweed tanks were harvested and restocked with $3 \mathrm{~kg}$ of shaded seaweed. Fish were removed from the fish tank to eliminate possible effects of fish on inorganic nitrogen concentrations in the system. Water in the sedimentation tank was internally circulated to preserve conditions as close as possible to those prevailing during normal operation. In order to assess possible ToxN production on the fish skins, inorganic nitrogen transformations were examined in a separate, aerated, clean tank containing fish.

Within the seaweed tanks, 3 locations were further examined for activity of nitrifying bacteria: the seaweed, the organic film on the tanks' walls and the tank water. To isolate these 3 possible nitrification sites, each of the 3 seaweed tanks was prepared and operated differently. Tank A, a shaded tank from which the seaweed was removed and in which the walls were scrubbed to remove the organic film, was examined for ToxN production potential in the water. Tank B, as Tank A but stocked with $3 \mathrm{~kg}$ of seaweed and not shaded, was examined for ToxN production potential on the seaweed fronds and in the water. In this tank, ammonia concentration was maintained at 100 to $150 \mu \mathrm{M}$ by a continuous dripping of an ammonium solution, to compensate for the ammonia assimilation by the seaweed. Tank C, a shaded tank in which the walls were not cleaned and without seaweed, was examined for ToxN production potential in the organic films on the walls and in the water. This organic film developed during several months under the operation regime described above. Neori et al. (1996) have shown that at such age, both forms of ToxN were produced in the system at significant rates

Laboratory experiments. All the laboratory experiments below were carried out in the following manner: organic film, removed from the walls of a seaweed tank of the model mariculture system, was incubated $\left(24 \pm 1^{\circ} \mathrm{C}\right.$, except for the temperature experiments) in $2 \mathrm{l}$ flasks filled with $1.5 \mathrm{l}$ of $0.5 \mathrm{~mm}$ filtered seawater from the same seaweed tanks. The organic film material from a tank added to each 1.51 flask was in proportion to the ratio between the area from which the film was collected and the water volume in the tank. That is, from a 20001 tank, with a wet wall area of $5 \mathrm{~m}^{2}$, the film from $37.5 \mathrm{~cm}^{2}$ was scrubbed into the $1.5 \mathrm{l}$ flask.
Effect of DO concentration on ToxN production potential: Three triplicated treatments (9 flasks in total) were bubbled by 3 gas mixtures, containing 3 different oxygen levels: (1) a mixture of $40 \%$ oxygen in nitrogen; (2) a mixture of $10 \%$ oxygen in nitrogen; (3) no oxygen (pure nitrogen gas). Filtered seawater from a seaweed tank served as a control for each treatment. Triplicate water samples, taken at 0,5 and $15 \mathrm{~h}$ from the onset of the experiment, were analyzed for total ammonia nitrogen (TAN), nitrite and nitrate. DO concentrations and $\mathrm{pH}$ levels were measured at the beginning and end of each incubation.

Effects of ammonia and $p H$ on ToxN production potential: The ToxN production potential in the film as a function unionized ammonia $\left(\mathrm{NH}_{3}\right)$ (in the range of 0 to $\left.0.5 \mathrm{mM} \mathrm{NH}_{3}\right)$ at $3 \mathrm{pH}$ levels $(7 \pm 0.2,8 \pm 0.2$ and $9 \pm 0.2$ ) was examined twice. The desired $\mathrm{NH}_{3}$ concentrations for each $\mathrm{pH}$ were attained by adding various amounts of ammonium salt to the water according to the equilibrium constant of ammonia, temperature and salinity of the water. Using the tables of Bower \& Bidwell (1978), the percentages of $\mathrm{NH}_{3}$ in TAN in seawater at $24^{\circ} \mathrm{C}$ were calculated to be $0.7,2$ and $17.3 \%$ for $\mathrm{pH} 7,8$ and 9, respectively. Tris (hydroxymethyl) aminomethane-maleic acid, Tris$\mathrm{HCl}$ and Tris (hydroxymethyl) aminomethane- $\mathrm{HCl}$ were used to maintain $\mathrm{pH}$ values of 7, 8 and 9, respectively. A pH meter (Radiometer PHM 84) with a glass electrode was used for $\mathrm{pH}$ measurements. Nitrite was added to the flasks at an initial concentration of $0.2 \mathrm{mM}$. Samples were taken at $0,2,6$ and $24 \mathrm{~h}$ after onset of the experiment for analyses of ammonia, nitrite and nitrate. At the same times, $\mathrm{pH}$ was measured. Solutions of $\mathrm{HCl}$ and $\mathrm{NaOH}$ were added to correct the $\mathrm{pH}$ when necessary.

Effect of temperature on ToxN production potential: Three temperature experiments were carried out. In each of them, 2 temperatures were compared for their effects on nitrogen transformations in the organic film from the seaweed tanks of the model mariculture system. In the second and third experiments, the interaction between the effects of $\mathrm{pH}$ and temperature on nitrogen transformations was also examined.

Temperature Expt 1 (January 1996): Treatments maintained at $16^{\circ} \mathrm{C}(\mathrm{L})$ and $21^{\circ} \mathrm{C}(\mathrm{H})$ were compared in quadruplicates. This temperature difference was the same experienced in the model mariculture system at that time (January). Ammonia and nitrite $(50 \mu \mathrm{M}$ final concentration of each) were added at the onset of the experiment to flasks which had been inoculated with organic film from a seaweed tank, as described above, at the 2 designated temperatures $24 \mathrm{~h}$ earlier. Two of the replicates from each treatment ( $\mathrm{LL}$ and $\mathrm{HH}$ ) were then kept at the initial temperature for $48 \mathrm{~h}$ afterwards. The other 2 replicates from each treatment ( $\mathrm{LH}$ and HL) were 
transferred $24 \mathrm{~h}$ after the onset of the experiment from 16 to $21^{\circ} \mathrm{C}$ and vice versa. These duplicates served as controls. Water samples were drawn from each flask for the analysis of ammonia, nitrite and nitrate at the onset of the experiment and then about every $8 \mathrm{~h}$ for $2 \mathrm{~d}$.

Two more experiments were carried out, to clarify the temperature effect and its interaction with $\mathrm{pH}$ (Focht \& Verstraete 1977).

Temperature Expt 2 (February 1996): Two different $\mathrm{pH}$ levels, 8 and 9, and 2 temperatures, 17.5 (L) and $28^{\circ} \mathrm{C}(\mathrm{H})$, were examined in triplicates for their effects on the nitrogen transformations. The $\mathrm{pH}$ was adjusted in the water in each flask, 6 flasks ( $3 \mathrm{~L}$ and $3 \mathrm{H}$ ) at $\mathrm{pH} 8$ and, 6 flasks ( $3 \mathrm{~L}$ and $3 \mathrm{H}$ ) at $\mathrm{pH}$ 9. The water in each flask was then aerated for several hours, to equilibrate the DO level. From then on, the experiment proceeded as in Expt 1 ( $24 \mathrm{~h}$ of equilibration with the organic film at the designated temperatures and then the addition of ammonia and nitrite at the onset of the experiment). Water samples were drawn from each flask for the analysis of ammonia, nitrite and nitrate at the onset of the experiment and then every about $10 \mathrm{~h}$ for $2 \mathrm{~d}$. Each sampling was accompanied by the measurement of $\mathrm{pH}$ and its adjustment, as described above.

Temperature Expt 3 (April 1996): A third temperature experiment was conducted, similar to the second one, except that the $\mathrm{L}$ temperature ranged from 18 to $19^{\circ} \mathrm{C}$, due to technical limitations of our culture room.

Chemical and physical analysis. Water samples were filtered through acid-washed, glass-fiber filters (Whatman GF/C) within 15 min of collection. The filtered samples were then refrigerated for up to $2 \mathrm{~d}$ before analysis by an Autoanalyzer (Technicon AAII). This storage had been shown in our laboratory to be absolutely safe (Krom et al. 1985). Nitrite and nitrate were analyzed as in Glibert \& Loder (1977), TAN as in Krom et al. (1985). Precision of each method in our laboratory is given in Krom et al. (1995). DO was measured with a YSI electrode (Yellow Springs Instrument Co.) after calibration against the Winkler method.

Statistical analysis. A multivariate analysis of the ToxN production potential. rates was made by SPSS software. Groups were first tested for normal variance. In the ammonia-pH study, the experiment date was taken as a third non-parametric independent variable

\section{RESULTS}

\section{Location and characterization of ToxN production potential in the model fish-seaweed mariculture system}

Nitrogen transformations in each of the compartments comprising the mariculture system were measured un- der conditions in which the flow of water through the compartments was entirely stopped for $24 \mathrm{~h}$.

Fish tank. DO concentrations in the fish tank (with the fish removed) during the $24 \mathrm{~h}$ period remained above $5.3 \mathrm{mg} \mathrm{l}^{-1}$, temperature ranged between 25 and $26.3^{\circ} \mathrm{C}$ and the $\mathrm{pH}$ between 7.92 and 8.12 (data not shown). Ammonia increased at an overall rate of $51 \mu \mathrm{mol} \mathrm{N} \mathrm{l}^{-1}$ (92 $\mathrm{mmol}$ tank $\left.\mathrm{k}^{-1}\right) \mathrm{d}^{-1}$, nitrite concentrations increased at a rate of $28 \mu \mathrm{mol} \mathrm{N} \mathrm{^{-1 }}\left(50 \mathrm{mmol} \operatorname{tank}^{-1}\right) \mathrm{d}^{-1}$, while nitrate concentrations varied inconsistently and decreased overall at a rate of $49 \mu \mathrm{mol} \mathrm{N} \mathrm{l^{-1 }}$ (88 mmol $\operatorname{tank}^{-1}$ ) $\mathrm{d}^{-1}$ (Fig. 2A)

Fish skin was not a site for nitrogen transformations as no ToxN accumulated in an ammonia-supplemented, clean tank stocked with fish (data not shown).

Sedimentation tank. DO concentration dropped to undetectable levels within $6 \mathrm{~h}$ after water flow was ceased while the temperature increased from 28 to $34^{\circ} \mathrm{C}$ after $12 \mathrm{~h}$ (data not shown). An increase in the nitrite concentration was measured in the first $2 \mathrm{~h}$ (Fig. 2B). Thereafter, for the next $8 \mathrm{~h}$, nitrite concentrations decreased to undetectable levels at an average rate of $4.9 \mu \mathrm{mol} \mathrm{l}{ }^{-1} \mathrm{~h}^{-1}\left(118 \mu \mathrm{mol} \mathrm{N} \mathrm{l} \mathrm{l}^{-1}\left[47 \mathrm{mmol} \operatorname{tank}^{-1}\right]_{\mathrm{d}}^{-1}\right)$. Nitrate concentrations decreased rapidly to undetectable levels at an average rate of $24 \mu \mathrm{mol} \mathrm{l}^{-1} \mathrm{~h}^{-1}\left(575 \mathrm{mmol} \mathrm{N} \mathrm{l} \mathrm{l}^{-1}\right.$ [230 $\mathrm{mmol} \operatorname{tank}^{-1}$ ] $\mathrm{d}^{-1}$ ). Ammonia accumulated at an overall rate of $26.9 \mu \mathrm{mol} \mathrm{l^{-1 }} \mathrm{h}^{-1}\left(0.65 \mathrm{mmol} \mathrm{N} \mathrm{l^{-1 }}\right.$ [258 mmol tank $\left.\mathrm{m}^{-1}\right] \mathrm{d}^{-1}$ ), with noteworthy leaps during the first $2 \mathrm{~h}$ and between 8 and $10 \mathrm{~h}$ after onset of measurements. The latter coincided with the disappearance of ToxN (nitrite and nitrate).

Seaweed tank. In the shaded seaweed tank, temperature increased from 27.5 to $31.5^{\circ} \mathrm{C}$, pH level ranged between 8.0 to 7.9 and $\mathrm{DO}$ concentration decreased from 5.5 to $5.0 \mathrm{mg} \mathrm{l}^{-1}$. While ammonia concentration first dropped and then stabilized (not including the addition of ammonium salt after $3 \mathrm{~h}$ ), concentrations of both nitrite and nitrate increased steadily during the entire $24 \mathrm{~h}$ of the experiment (Fig. 2C). Overall accumulation rates of

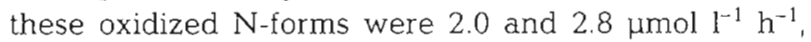
respectively $\left(0.048\right.$ and $0.067 \mathrm{mmol} \mathrm{N}^{-1} \mathrm{~d}^{-1}$, and 102 and $143 \mathrm{mmol} \operatorname{tank}^{-1} \mathrm{~d}^{-1}$, respectively), totaling $0.73 \mathrm{~mol} \mathrm{~d}^{-1}$ in the 3 seaweed tanks. Overall, $58 \%$ of the ToxN accumulation was in the form of nitrate (complete nitrification). Absolute and relative rates of ammonia and nitrite oxidation varied over the experimental period. During the first morning, nitrite and nitrate accumulated at rates of 1 and $2.2 \mu \mathrm{mol} \mathrm{l}^{-1} \mathrm{~h}^{-1}$, respectively. Of the total ToxN accumulated, $69 \%$ was recovered as nitrate. That afternoon, the respective rates of the 2 processes increased to 2 and $2.6 \mu \mathrm{mol} \mathrm{l}{ }^{1} \mathrm{~h}^{-1}$, respectively, with $56.5 \%$ of the accumulated ToxN recovered as nitrate. During the early evening, nitrite and nitrate accumulated. still faster, at rates of 2.8 and $3.1 \mu \mathrm{mol} \mathrm{l^{-1 }} \mathrm{h}^{-1}$, respectively $(52.5 \%$ nitrate recovery), and during the 


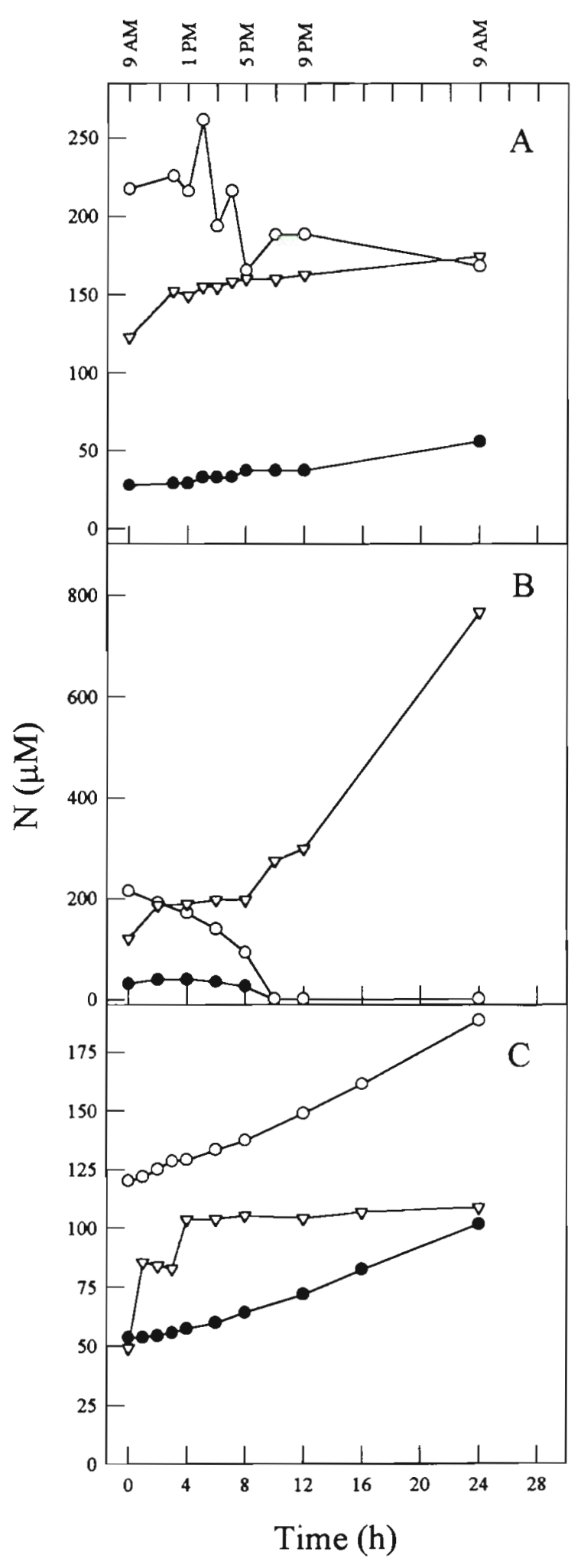

Fig. 2. Concentrations of $(\boldsymbol{\nabla})$ TAN, ( $)$ nitrite and (O) nitrate in (A) the fish tank, (B) the sedimentation tank and (C) the seaweed tank. Tanks were operated without water exchange over a $24 \mathrm{~h}$ period night and early morning, the rates were 2.4 and $3.4 \mu \mathrm{mol} \mathrm{l}^{-1} \mathrm{~h}^{-1}$, respectively (58\% nitrate recovery).

\section{Location of the ToxN production within the seaweed tanks}

ToxN production potential in the water (Tank $A$, Table 1). DO concentration ranged between 6.3 and $5.7 \mathrm{mg} \mathrm{l}^{-1}$. The $\mathrm{pH}$ was rather constant at 8.45 to 8.55 and temperature ranged between 27.1 and $31.1^{\circ} \mathrm{C}$ (data not shown). A stable net ToxN production rate of $0.12 \mathrm{~mol} \mathrm{~N} \mathrm{~d}^{-1}$ was measured throughout the entire $48 \mathrm{~h}$ of the experiment. Only $50 \%$ of the accumulated ToxN was nitrified completely to nitrate (Table 1).

ToxN production potential on the seaweed fronds (Tank B, Table 1, Fig. 3). The highest peak of DO concentration, $8.7 \mathrm{mg} \mathrm{l}^{-1}$, was measured in the morning. DO concentration declined to the lowest level of $5.1 \mathrm{mg} \mathrm{l}^{-1}$ at night. A pH of 9.92 was measured at noon and it declined to 8.59 at night. Temperature varied from 25.5 at night to $31.8^{\circ} \mathrm{C}$ in the afternoon. In this tank ToxN accumulation showed a diurnal pattern. Overall, the rate of ToxN accumulation on the seaweed in the whole tank averaged $0.08 \mathrm{~mol} \mathrm{~N} \mathrm{~d}^{-1}$. During the day, most of the accumulated ToxN $\left(1.56 \mu \mathrm{mol} \mathrm{l} \mathrm{l}^{-1} \mathrm{~h}^{-1}\right.$, $2.8 \mathrm{mmol} \mathrm{N} \operatorname{tank}^{-1} \mathrm{~h}^{-1}$ ) was nitrate. In contrast, at night, nitrite was the predominant oxidized nitrogen form that accumulated (Table 1, Fig, 3). On average, 90\% and $30 \%$ of the accumulated ToxN was nitrate during the day and nighttime, respectively. The highest $\mathrm{pH}$ and temperatures coincided with the switch from nitrate to nitrite accumulation. The periods in which nitrite was the dominant ToxN accumulation product coincided with highest levels of $\mathrm{pH}$, temperature and $\mathrm{NH}_{3}$ and with lower levels of DO (Fig. 3).

ToxN production potential in biofilm on the tanks' walls (Tank C, Table 1). DO concentration varied between 5.7 and $6.3 \mathrm{mg} \mathrm{l}^{-1}$ and was negatively correlated with water temperature (data not shown). Temperature varied between 26.7 and $31.3^{\circ} \mathrm{C}$ while $\mathrm{pH}$ levels ranged between 8.31 and 8.56 . Relative to other sites within the seaweed tank, the highest net ToxN production potential was measured here (0.345 mol d $\left.\mathrm{m}^{-1} ; 53 \mathrm{mmol} \mathrm{N} \mathrm{m}^{-2} \mathrm{~d}^{-1} ; 0.74 \mathrm{~g} \mathrm{~N} \mathrm{~m}^{-2} \mathrm{~d}^{-1}\right)$ (Table 1). Over half of the accumulated ToxN was recovered as nitrate in this treatment.

Factors affecting ToxN production in the organic film on the seaweed tanks-laboratory experiments

Effect of DO concentration on ToxN production potential. The rate of ToxN accumulation was similar at 9.3 and $4.5 \mathrm{mg} \mathrm{O}_{2} \mathrm{l}^{-1}$ (Table 2). At undetectable 
Table 1. Nitrite and nitrate potential production rates ( $\mu \mathrm{mol} \mathrm{l}^{-1} \mathrm{~h}^{-1} \pm \mathrm{SE}$ ) over $48 \mathrm{~h}$ in (A) seaweed tank without seaweed and without wall growth, (B) seaweed tank with seaweed and without wall growth, and (C) seaweed tank without seaweed and with wall growth

\begin{tabular}{|lllccc|}
\hline Tank & Period examined & Ammonia & Nitrate & ToxN & Nitrate/ToxN \\
\hline A & Entire 48 h & $-2.38 \pm 0.2$ & $1.15 \pm 0.02$ & $2.34 \pm 0.03$ & 0.5 \\
B & Day 1 & $1.56 \pm 0.04$ & $1.52 \pm 0.14$ & 1.0 \\
& Night 1 & $0.26 \pm 0.13$ & $1.2 \pm 0.09$ & 0.2 \\
& Day 2 & $1.94 \pm 0.28$ & $2.31 \pm 0.21$ & 0.8 \\
& Night 2 & $0.28 \pm 0.10$ & $1.09 \pm 0.09$ & 0.26 \\
C & Entire 48 h & $-4.50 \pm 0.55$ & $3.7 \pm 0.08$ & $6.75 \pm 0.07$ & 0.55 \\
\hline
\end{tabular}

between 8 and 9 did not affect either stages of ToxN production potential at any temperature (Table 5). The trends but not the extents of the temperature effect between the 3 experiments should be compared, as each experiment took place at a different time, and therefore the environmental conditions and the precise characteristics of the organic film differed.

In temperature Expt 1, a temperature increase of $5^{\circ} \mathrm{C}$ caused a significant ( $p<0.05$ ) near doubling of the ToxN production potential already after $24 \mathrm{~h}$ (data not shown). Switching

levels of DO, this rate dropped by $76 \%$. The oxidation rate of nitrite to nitrate dropped insignificantly between 9.3 to $4.5 \mathrm{mg} \mathrm{O} \mathrm{l}^{-1}$ but nitrate was consumed at undetectable DO levels. Nitrite, however, did accumulate even at undetectable levels of DO (Table 2).

Interaction between the effects of ammonia concentration and $\mathrm{pH}$ level on ToxN production potential in the organic film from the wall of a seaweed tank. No significant differences in the rates of the 2 nitrification steps were found between the 2 replicate experiments (1-way ANOVA). Therefore, the data from both experiments were combined in the following statistical analyses.

In a 2-way ANOVA to evaluate the combined effects of $\mathrm{NH}_{3}$ and $\mathrm{pH}$ on nitrification rate, the only informative effects were those of $\mathrm{pH}$ on ToxN accumulation (Table 3a; $p=0.088,1$-tail) and the negative combined effects of $\mathrm{pH}$ and ammonia on nitrate accumulation (Table $3 b ; p=0.07,1$-tail). In a 1-way ANOVA for effect of $\mathrm{pH}$ on ToxN accumulation, it was absolutely significant $\left(F_{[2.18]}=3.71 ; 0.01<p<0.05\right)$. The $\mathrm{pH}$ level significantly $(p<0.05)$ influenced the rate of accumulation of ToxN, so that at $\mathrm{pH} 7$ the rate of ToxN production was less than half that at either $\mathrm{pH} 8$ or 9 (Table 4). However, the $\mathrm{pH}$ level did not significantly influence the absolute rate of nitrate accumulation. There was only an indication of a lower nitrate accumulation rate at $\mathrm{pH} 9$ (Table 4). At pH 7, three-quarters of the accumulated ToxN (i.e. of total nitrification) was nitrate and at higher $\mathrm{pH}$ levels this ratio dropped to a quarter or less (Table 4). In the range of concentrations tested (up to $0.5 \mathrm{mM}$ ), unionized ammonia did not significantly affect ToxN production potential.

Interaction between the effects of temperature and pH on ToxN production potential. The rise in temperature by 5 to $10^{\circ} \mathrm{C}$ significantly increased the rates of total ToxN production potential and reduced the ratio between the accumulation of nitrate and ToxN (Table 5). On the contrary, as was found in the ammonia-pH experiment described above, a $\mathrm{pH}$ change between 2 replicates of the treatments after $24 \mathrm{~h}$, that is, the transfer of 2 flasks incubated at the low temperature to the high temperature (LH) and vice versa (HL), also switched the relationship between the rates, confirming the results of the temperature effects in the first $24 \mathrm{~h}$.

In temperature Expts 2 and 3, a temperature difference of about $10^{\circ} \mathrm{C}$ for $48 \mathrm{~h}$ caused significant increases of the ToxN production potential by up to 3 -fold at both $\mathrm{pH}$ values and slightly decreased the ratio between the accumulation of nitrate and ToxN (Table 5). Hence, at higher temperatures more nitrite accumulated.

\section{DISCUSSION}

In the hypertrophic model ecosystem studied, the production and consumption of ToxN was most probably mediated by nitrifying and denitrifying bacteria although, based on our results, the influence of other nitrogen transformation processes cannot be excluded. In addition to autotrophic nitrifiers, heterotrophic nitrifiers might have been responsible for ammonia oxidation to nitrite and nitrate. This latter process usually takes place in organic-rich, low-pH environments (Killham 1986) and as such it might be assumed that its contribution to ammonia oxidation in our experimental system was minor. Dissimilatory nitrate reduction to ammonia is an additional process in which nitrite forms an intermediate product. Usually this process takes place under electron-acceptor limiting conditions, i.e. in environments with high $\mathrm{C} / \mathrm{N}$ ratios (Tiedje 1988). The process can be differentiated from denitrification by measurement of nitrogen gases produced during nitrate reduction. As in the present study no such measurements were conducted, the possibility that dissimilatory nitrate reduction to ammonia also affected the nitrate reduction and nitrite accumulation rates in the system cannot be discarded. In this study, the $\mathrm{N}$-deficit of the system cor- 


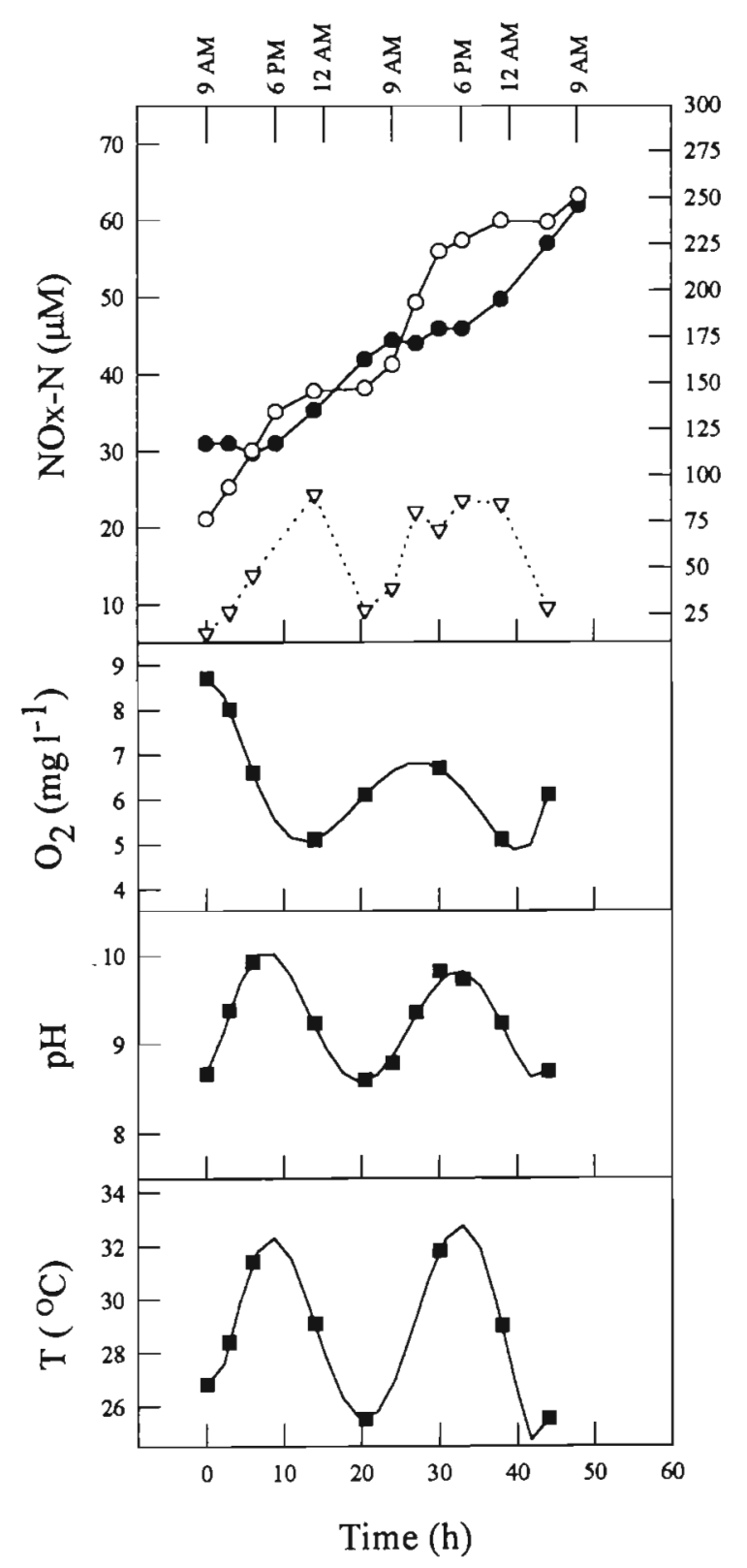

Fig. 3. (Top frame) concentrations of $(\boldsymbol{\nabla})$ unionized ammonia, $(\bullet)$ nitrite and (o) nitrate, and (lower frames) dissolved oxygen, $\mathrm{pH}$ and temperature, in a seaweed tank during $48 \mathrm{~h}$. Concentrations of unionized ammonia were calculated from TAN concentrations and $\mathrm{pH}$, according to Bower \& Bidwell (1978)

responded to the measured nitrate reduction. It seems, therefore, that denitrification and not dissimilatory nitrate reduction to ammonia was responsible for most of the nitrate reduction in this system.

Based on the results obtained in this study it is possible to locate the important processes in the studied experimental hypertrophic ecosystem and identify the factors that underlie them.
Table 2. Effect of oxygen levels on nitrite and nitrate potential production rates ( $\mu \mathrm{mol} \mathrm{l^{-1 }} \mathrm{h}^{-1} \pm \mathrm{SE}$ ) in organic film scraped from a seaweed tank; laboratory incubations. Values with the same superscript are not significantly different $(p<0.05)$, using Student-Newman Keuls post-hoc tests

\begin{tabular}{|ccrc|}
\hline Oxygen $\left(\mathrm{mg} \mathrm{l}^{-1}\right)$ & ToxN & Nitrate & Nitrate/ToxN \\
\hline 9.3 & $1.88 \pm 0.14^{\mathrm{a}}$ & $0.48 \pm 0.19^{\mathrm{a}}$ & $0.25 \pm 0.04$ \\
4.5 & $1.87 \pm 0.20^{\mathrm{a}}$ & $0.35 \pm 0.05^{\mathrm{a}}$ & $0.19 \pm 0.03$ \\
$\sim 0$ & $0.45 \pm 0.09^{\mathrm{b}}$ & $-0.35 \pm 0.33^{\mathrm{b}}$ & $\cdot$ \\
& & \\
\hline
\end{tabular}

Table 3. Two-way ANOVA of potential production rate of (a) ToxN and (b) nitrate in organic film scraped from a seaweed tank, for $\mathrm{pH}$ and $\mathrm{NH} 3$ effects; laboratory incubations. The experimental design was factorial, with 3 levels of $\mathrm{NH}_{3}$ concentration ranges $(<50 \mu \mathrm{M}, 60$ to $200 \mu \mathrm{M}$, and 210 to $500 \mu \mathrm{M})$ and 3 levels of $\mathrm{pH}(7,8$, and 9$)$

\begin{tabular}{|lcrc|}
\hline Source & df & MS & $F$ \\
\hline (a) ToxN & & & \\
$\mathrm{pH}$ & 2 & 11.41 & 2.65 \\
$\mathrm{NH}_{3}$ & 2 & 4.60 & 1.07 \\
$\mathrm{pH} \times \mathrm{NH}_{3}$ & 3 & 0.74 & 0.14 \\
(b) Nitrate & & & \\
$\mathrm{pH}$ & 2 & 0.65 & 1.40 \\
$\mathrm{NH}_{3}$ & 2 & 0.17 & 0.36 \\
$\mathrm{pH} \times \mathrm{NH}_{3}$ & 3 & 0.81 & 2.40 \\
\hline
\end{tabular}

Table 4. Potential production rates $\left(\mu \mathrm{mol} \mathrm{l}^{-1} \mathrm{~h}^{-1} \pm \mathrm{SE}\right)$ of ToxN and nitrate as a function of $\mathrm{pH}$ in organic film scraped from a seaweed tank; laboratory incubations. Values with the same superscript are not significantly different ( $p<0.05)$, using Student-Newman Keuls post-hoc tests. $\mathrm{NH}_{3}$ data were not tabulated because of insignificant effect (see in text)

\begin{tabular}{|cccc|}
\hline $\mathrm{pH}$ & ToxN & Nitrate & Nitrate/ToxN \\
\hline 7 & $0.20 \pm 0.13^{\mathrm{b}}$ & $0.13 \pm 0.06$ & $0.77 \pm 0.26^{\mathrm{a}}$ \\
8 & $0.50 \pm 0.25^{\mathrm{a}}$ & $0.13 \pm 0.06$ & $0.23 \pm 0.08^{\mathrm{b}}$ \\
9 & $0.44 \pm 0.23^{\mathrm{ab}}$ & $0.07 \pm 0.07$ & $0.13 \pm 0.13^{\mathrm{b}}$ \\
\hline
\end{tabular}

\section{Site of ToxN production potential}

Most of the ToxN production and the highest nitrification rate (ToxN production potential) within the system were found in the seaweed tanks. Most of the nitrifying activity was found within the organic film on the submerged walls of these tanks, and only a little in the water or on the seaweed. The rates of nitrification per surface of the wall (up to $0.74 \mathrm{~g} \mathrm{~N} \mathrm{~m}^{-2} \mathrm{~d}^{-1}$ ) were nearly 3 times higher than the rates reported by Nijhof \& Bovendeur (1990) in a seawater nitrification biofilter (up to $0.28 \mathrm{~g} \mathrm{~N} \mathrm{~m}^{-2} \mathrm{~d}^{-1}$ ) and also higher than the maxi- 
Table 5. Potential production rates of ToxN and nitrate $\left(\mu \mathrm{mol} \mathrm{l}^{-1} \mathrm{~h}^{-1} \pm \mathrm{SE}\right)$ at different temperatures and $\mathrm{pH}$ levels in organic film obtained from a seaweed tank; laboratory incubations. Expt 1 . Incubation for $48 \mathrm{~h}$ at $16 \pm 1^{\circ} \mathrm{C}$ (LL) or at $21 \pm 1^{\circ} \mathrm{C}(\mathrm{HH})$; for $24 \mathrm{~h}$ at $16 \pm 1^{\circ} \mathrm{C}$ followed by $24 \mathrm{~h}$ at $21 \pm 1^{\circ} \mathrm{C}(\mathrm{LH})$; for $24 \mathrm{~h}$ at $21 \pm 1^{\circ} \mathrm{C}$ followed by $24 \mathrm{~h}$ at $16 \pm 1{ }^{\circ} \mathrm{C}$ (HL). Expt 2: Incubation for $48 \mathrm{~h}$ at $17.5 \pm$ $1^{\circ} \mathrm{C}(\mathrm{L})$ or $28 \pm 1^{\circ} \mathrm{C}(\mathrm{H})$. Expt 3: Incubation for 48 h at $18.5 \pm 1^{\circ} \mathrm{C}(\mathrm{L})$ or $28 \pm 1^{\circ} \mathrm{C}$ $(\mathrm{H})$. Values with the same superscript are not significantly different $(\mathrm{p}<0.05)$, using Student-Newman Keuls post-hoc tests

\begin{tabular}{|c|c|c|c|c|c|}
\hline Expt & $\mathrm{pH}$ & Temperature & ToxN & Nitrate & Nitrate/ToxN \\
\hline 1 & 8.2 & LL & $1.97 \pm 0.38^{c}$ & $0.33 \pm 0.01^{\mathrm{b}}$ & $0.17 \pm 0.05$ \\
\hline 1. & 8.2 & $\mathrm{LH}$ & $2.77 \pm 0.11^{b}$ & $0.45 \pm 0.01^{\circ}$ & $0.16 \pm 0.01$ \\
\hline 1 & 8.2 & $\mathrm{HH}$ & $3.61 \pm 0.09^{d}$ & $0.38 \pm 0.03^{\mathrm{ab}}$ & $0.1 \pm 0.006$ \\
\hline 1 & 8.2 & HL & $1.88 \pm 0.22^{6}$ & $0.30 \pm 0.03^{a b}$ & $0.16 \pm 0.01$ \\
\hline 2 & 8 & $\mathrm{~L}$ & $0.19 \pm 0.08^{b}$ & $0.08 \pm 0.01$ & $0.49 \pm 0.10^{\alpha}$ \\
\hline 2 & 8 & $\mathrm{H}$ & $0.1^{\circ}$ & $0.05 \pm 0.10$ & $0.32^{\circ}$ \\
\hline 2 & 9 & $\mathrm{~L}$ & $0.25 \pm 0.03^{\mathrm{ab}}$ & $0.09 \pm 0.03$ & $0.37 \pm 0.10^{\alpha}$ \\
\hline 2 & 9 & $\mathrm{H}$ & $0.37 \pm 0.06^{\mathrm{d}}$ & $0.04 \pm 0.01$ & $0.10 \pm 0.02^{b}$ \\
\hline 3 & 8 & L & $0.17 \pm 0.03^{b}$ & $0.06 \pm 0.02^{b}$ & $0.34 \pm 0.07$ \\
\hline 3 & 8 & $\mathrm{H}$ & $0.52 \pm 0.08^{a}$ & $0.13 \pm 0.05^{\circ}$ & $0.25 \pm 0.06$ \\
\hline 3 & 9 & $\mathrm{~L}$ & $0.20 \pm 0.07^{b}$ & . & .. \\
\hline 3 & 9 & $\mathrm{H}$ & $0.52 \pm 0.07^{a}$ & $0.12 \pm 0.01^{\mathrm{a}}$ & $0.23 \pm 0.03$ \\
\hline \multicolumn{6}{|c|}{$\begin{array}{l}\text { "Only } 1 \text { replicate survived } \\
\text { " Nitrate reduction }\end{array}$} \\
\hline
\end{tabular}

an additional factor preventing the development of nitrifiers on it.

No clear evidence was obtained on the contribution of nitrification to the nitrogen transformations occurring in the fish tank, but the overall rates were low there. Nitrite in this tank was produced not only by nitrification but probably also by denitrification as nitrate concentrations at times increased (nitrification) and at other times decreased (denitrification). The latter process might occur in the less aerated areas within this tank. Evidence, however, that the observed nitrite buildup resulted also from nitrification and not only from denitrification was provided in a previous study of this experimental system (Krom et al. 1995). There, both nitrite and nitrate accumulated in the fish tank. This nitrification, however, occurred in the recirculated water while no nitrification occurred on the walls of the fish tank. The organic mum rates recorded in freshwater nitrification biofilters (van Rijn 1996). The stable nature of the system, the abundant surface area provided by the organic matter, the constant flow of DO-rich water along the walls, the high ambient water temperatures and the ample supply of ammonia, released by degradation and ammonification of organic matter (as found in laboratory experiments), probably explain this high nitrification rate. Similar nitrification rates were reported by Caffrey et al. (1993) from a semi-artificial, marine sediment microcosm enriched by labile organic matter.

The overall ToxN production (nitrification) potential for the 3 seaweed-biofilter tanks of $0.73 \mathrm{~mol} \mathrm{~N} \mathrm{~d} \mathrm{~d}^{-1}$ equals about $33 \%$ of the total daily $\mathrm{N}$ input (fish excretions). This potential, measured with the addition of ample ammonia, is about 3 times higher then the actual values determined during normal mariculture operation by Krom et al. (1995) for this model ecosystem. Therefore, the overall normal ammonia oxidation process was substrate-limited, most probably as a consequence of competition by the seaweed.

Competition for ammonia, based on the differences in ammonia affinity between seaweed and nitrifying bacteria that settle on them (see in Lobban et al. 1985), might explain why nitrification on the seaweed was very low. It may also be possible that the fast seaweed growth and concomitant harvest could not be matched by the slow-growing (Nijhof \& Bovendeur 1990) seawater nitrifiers. The high $\mathrm{pH}$ values associated with the surface of the photosynthesizing seaweed might be film on the walls of this tank was much thinner in appearance than that in the seaweed tanks, probably as a result of grazing and scraping by the fish.

In the sedimentation tank, ammonification and denitrification were the dominant nitrogen transformation processes as attested by the fast rate of TAN accumulation and the depletion of ToxN. It might be assumed, however, that within the oxygenated water flowing through this tank some nitrification took place. This was supported by the finding that nitrite and nitrate were produced upon aerobic incubation in the laboratory of organic film obtained from this tank (not shown). In the field test, during the initial aerobic period, nitrification and denitrification in the sedimentation tank occurred simultaneously and ammonia was apparently produced and consumed at approximately even rates. After several hours, once DO and ToxN were depleted, ammonia accumulated rapidly. Therefore, the value of denitrification rate, as determined in this study by the disappearance of ToxN, was an underestimate of the actual denitrification rate in the sedimentation basin under the normal, partially aerated operation conditions. Considering the ammonia oxidation and subsequent reduction of oxidation products, the actual denitrification rate rises from an apparent value of $29 \mu \mathrm{mol} \mathrm{l} \mathrm{l}^{-1} \mathrm{~h}^{-1}$ to a more realistic value of $49 \mu \mathrm{mol} \mathrm{l}^{-1} \mathrm{~h}^{-1}$, or $0.47 \mathrm{~mol} \operatorname{tank}^{-1} \mathrm{~d}^{-1}$, about $19 \%$ of the entire $\mathrm{N}$-input. It is instructive to notice that this value is about the same as the $\mathrm{N}$-deficit described for the $\mathrm{N}$-budget of this system in Krom et al. (1995). 


\section{Environmental factors affecting ToxN production}

As observed in other nitrifying systems (Belser 1979, Kaplan 1983), pH, DO and temperature were shown to affect the rates of oxidation of ammonia and nitrite by the nitrifying bacteria present in this marine model ecosystem. TAN levels recorded in the model system did not influence Tox $N$ production potential at levels that have been reported to inhibit nitrification in freshwater systems (Belser 1979). At the levels of unionized ammonia examined in this study, oxidation rates of ammonia and nitrite were not affected. Marginally better nitrification rates were found at ambient ammonia concentrations of $100 \mu \mathrm{M}$. At these optimal concentrations, nitrite accumulated for reasons explained below.

The $\mathrm{pH}$ optimum for nitrification was $\mathrm{pH} 8$ as found in freshwater systems (Focht \& Verstraete 1977). The interactions of the effects of $\mathrm{pH}$ with ammonia and temperature were weak.

At DO concentrations of 4.5 and $9.3 \mathrm{mg} \mathrm{l}^{-1}, \mathrm{DO}$ did not limit nitrifying activity. This finding is in accordance with work on freshwater nitrifying bacteria, in which $K_{\mathrm{m}}$ for oxygen of Nitrosomonas and Nitrobacter ranged from 0.3 to $1.0 \mathrm{mg} \mathrm{O} \mathrm{O}_{2} \mathrm{l}^{-1}$ (Focht \& Verstraete 1977). Ammonia-oxidizing nitrifiers are considered less sensitive to changing or extreme environmental factors than nitrite-oxidizing nitrifiers (Focht \& Verstraete 1977. Belser 1979, Kaplan 1983, Ward 1986). With respect to oxygen this was also evident in our experiments as it was found that in flasks flushed with nitrogen gas (undetectable DO), ammonia oxidation took place together with nitrate reduction. The higher sensitivity to environmental conditions of nitrite oxidizers relative to ammonia oxidizers was also found at high ambient temperatures in high $\mathrm{pH}$ waters. Under these conditions, relative to nitrite oxidation, ammonia oxidation increased and nitrite accumulated. Similar observations were made on nitrite-oxidizing bacteria in sewage (Wong-Chong \& Loehr 1978) and in other freshwater environments (Fdz-Polanco et al. 1996). Catalan-Sakairi et al. (1996) suggested that at high pH values, nitrite-oxidizing nitrifiers are limited by available inorganic carbon since at high $\mathrm{pH}$ values most of the inorganic carbon is either present in the bicarbonate or carbonate forms.

It is believed that nitrite oxidizers are more photosensitive than ammonia oxidizers (Olson 1981). Strong light on a nitrifying bacterial population can therefore lead to nitrite accumulation. The only non-shaded compartment of the experimental system studied here was the seaweed's. There, ToxN was produced mainly on the walls, which were shaded by the seaweed themselves. Incomplete nitrification occurred mainly at night. Therefore, light does not seem to exert any direct effect on nitrification in this model system.

\section{CONCLUSIONS}

Inorganic nitrogen transformations in hypertrophic ecosystems are complex and, rather than understanding all of these processes, the aim of this study was to locate and identify the process(es) which caused the observed nitrite accumulation in this model hypertrophic marine system. It is shown that incomplete nitrification taking place within the organic films in the seaweed tanks contributed to most of the nitrite in the system. Elevated temperatures and $\mathrm{pH}$ values during the day led to higher overall nitrification rates due to increased ammonia oxidation rates. As a result, from the early afternoon nitrite accumulated. Ammonia oxidation rates dropped during the night due to a decrease in temperature and $\mathrm{pH}$ values, so that by early morning nitrate again became the dominant product of nitrification. Without photosynthetic activity (as in the shaded seaweed tanks), $\mathrm{pH}$ values did not increase. Temperature variation alone was apparently not sufficient to change the relative rates of the 2 nitrification processes.

It is concluded that total nitrification in this oxic hypertrophic system was correlated, in addition to ammonia and DO, to high ambient temperatures and the abundant immobilization surfaces provided by the walls of the seaweed tanks. Nitrite accumulation in the system was enhanced by the effect of high temperatures and high $\mathrm{pH}$ values on nitrification in the seaweed tanks and to a lesser extent, by the effect of low DO concentrations on the balance between nitrification and denitrification in the fish and sedimentation tanks.

Acknowledgements. This research was funded by grant 3035 from the European Commission, DG XII-B and the Israeli Ministry of Science and Technology to A.N.; O.D. was supported part of the time by a scholarship from the Rhoda and Jordan Baruch Fellowship. We thank Dr Wayne Knibb for his help with statistical analyses and data interpretation and Dr R. J. Haroun Tabraue for his advice. This work was conducted in partial fulfillment of the requirements for the M.Sc. degree granted to O.D. by the Hebrew University of Jerusalem.

\section{LITERATURE CITED}

Almeida JS, Reis MAM, Carrondo MJT (1995) Competition between nitrate and nitrite reduction in denitrification by Pseudomonas fluorescens. Biotechnol Bioengng 46: $476-484$

Barak Y, Tal Y, van Rijn J (1998) Light-mediated nitrite accumulation during denitrification by Pseudomonas sp. strain JR12. Appl Environ Microbiol 64:813-817

Belser LW (1979) Population ecology of nitrifying bacteria. Annu Rev Microbiol 33:309-333

Betlach MR, Tiedje JM (1981) Kinetic explanation for accumulation of nitrite, nitric oxide and nitrous oxide during bacterial denitrification. Appl Environ Microbiol 42: 1074-1084

Blackburn HT, Lund BA, Krom MD (1988) C- and N-mineral- 
ization in the sediments of earthen marine fishponds. Mar Ecol Prog Ser 44:221-227

Bower CE, Bidwell JP (1978) Ionization of ammonia in seawater: effect of temperature, $\mathrm{pH}$, and salinity. J Fish Res Bd Can 35:1012-1016

Caffrey JM, Sloth NP, Kaspar HF, Blackburn TH (1993) Effect. of organic loading on nitrification and denitrification in a marine sediment microcosm. FEMS Microbiol Ecol 12: $159-167$

Catalan Sakairi MA, Yasuda K, Matsumura M (1996) Nitrogen removal in seawater using nitrifying and denitrifying bacteria immobilized in porous cellulose carrier. Water Sci Technol 34:267-274

Codispoti LA, Friederich GE, Packard TT, Glover HE, Kelly PJ, Spinrad RW, Barber RT, Elkins JW, Ward BB, Lipschultz F, Lostaunau N (1986) High nitrite levels off Northern Peru: a signal of instability in the marine denitrification rate. Science 233:1200-1202

Fdz-Polanco F, Villaverde S, Garcia PA (1996) Nitrite accumulation in submerged biofilters-combined effects. Water Sci Technol 34:371-378

Focht DD, Verstraete W (1977) Biochemical ecology of nitrification and denitrification. In: Alexander $M$ (ed) Advances in microbial ecology, Vol 1. Plenum Press, New York, p 135-214

Forster JRM (1974) Studies on nitrification in marine biological filters. Aquaculture 4:387-397

Glibert PL, Loder TC (1977) Automated analysis of nutrients in seawater: manual of techniques. Woods Hole Oceanogr Inst Tech Rep: WHOI-77-47

Helder W, de Vries RTP (1983) Estuarine nitrite maxima and nitrifying bacteria (Ems-Dollard Estuary). Neth J Sea Res $17: 1-18$

Hochstein LI, Betlach M, Krtikos G (1984) The effect of oxygen on denitrification during steady-state growth of Paracoccus halodenitrificans. Arch Microbiol 137:74-78

Kaplan WA (1983) Nitrification. In: Carpenter EJ, Capone DG (eds) Nitrogen in the marine environment. Academic Press, New York, p 139-190

Killham K (1986) Heterotrophic nitrification. In: Prosser JI (ed) Nitrification. Spec Publ of Soc for General Microbiology no. 20, IRL Press, Oxford, p 117-126

Krom MD, Neori A (1989) A total nutrient budget for an experimental intensive fishpond with circularly moving seawater. Aquaculture 83:345-358

Krom MD, Grayer S, Davidson A (1985) An automated method of ammonia determination for use in mariculture. Aquaculture 44:153-160

Krom MD, Ellner S, van Rijn J, Neori A (1995) Nitrogen and phosphorus cycling and transformations in a prototype 'non-polluting' integrated mariculture system, Eilat, Israel. Mar Ecol Prog Ser 118:25-36

Editorial responsibility: Otto Kinne (Editor),

Oldendorf/Luhe, Germany
Lobban CS, Harrison PJ, Duncan MJ (1985) The physiological ecology of seaweeds. Cambridge University Press. Cambridge

Neori A, Cohen I, Gordin H (1991) Ulva lactuca biofilters for marine fishpond effluents II. growth rate, yield and C:N ratio. Bot Mar 34:483-489

Neori A, Ellner SP, Boyd CE, Krom MD (1993) The integration of seaweed biofilters with intensive fish ponds to improve water quality and recapture nutrients. In: Moshiri GA (ed) Constructed wetlands for water quality improvement. Lewis Publishers, Boca Raton, FL, p 603-607

Neori A, Krom MD, Ellner SP, Boyd CE, Popper D, Rabinovitch R, Davison PJ, Dvir O, Zuber D, Ucko M, Angel D, Gordin H (1996) Seaweed biofilters as regulators of water quality in integrated fish-seaweed culture units. Aquaculture 141:183-199

Nijhof M, Bovendeur J (1990) Fixed film nitrification characteristics in sea-water recirculation fish culture systems. Aquaculture 87:133-143

Olson RJ (1981) Differential photoinhibition of marine nitrifying bacteria: a possible mechanism for the formation of the primary nitrite maximum. J Mar Res 39:227-238

Paasche E (1988) Pelagic primary production in nearshore waters. In: Blackburn HT, Sørensen $J$ (eds) Nitrogen cycling in coastal marine environments. SCOPE, John Wiley \& Sons Ltd, Chichester, p 33-58

Poxton MG, Murray KR, Linfoot BT, Poolay ABW (1981) The design and performance of biological filters in an experimental mariculture facility. In: Tiews K (ed) Proc world symp on aquaculture in heated effluents and recirculation systems, Stavanger 28-30 May 1980, Vol I. Heenemann, Berlin, p 370-382

Rysgaard S, Risgaard-Petersen N, Sloth NP (1996) Nitrification, denitrification, and nitrate ammonification in sediments of two coastal lagoons in Southern France. Hydrobiologia 329:133-141

Tiedje JM (1988) Ecology of denitrification and dissimilatory nitrate reduction to ammonium. In: Zehnder AJB (ed) Biology of anaerobic microorganisms. John Wiley \& Sons Inc, New York, p 179-244

Van Rijn J (1996) The potential for integrated biological treatment systems in recirculating fish culture: a review. Aquaculture 139:181-201

Van Rijn J, Tal Y, Barak Y (1996) Influence of volatile fatty acids on nitrite accumulation by a Pseudomonas stutzen strain isolated from a denitrifying fluidized bed reactor. Appl Environ Microbiol 62:2615-2620

Ward BB (1986) Nitrification in marine environments. In: Prosser JI (ed) Nitrification. Spec Publ of Soc for General Microbiology no. 20, IRL Press, Oxford, p 157-184

Wong-Chong GM, Loehr RC (1978) Kinetics of microbial nitrification: nitrite-nitrogen oxidation. Water Res 12:605-609

Submitted: July 7, 1998; Accepted: January 7, 1999

Proofs received from author(s): April 27, 1999 